\title{
Gonna be on my fucking period in boomtown, souuuunndd thanks Mother Nature: Using Twitter to Find Multimodal Creativity and Embodied Instant Metaphors
} "Vai ser bem na época da minha mestruação em Boomtown, muuuiiito obrigada Mãe Terra: Utilizando
dados do twitter para encontrar criatividade multimodal e metáforas corporificadas instantâneas".

\section{Lacey Okonski \\ Luciane Corrêa Ferreira}

Universidade Federal do Minas Gerais - UFMG - Minas Gerais - Brasil

\begin{abstract}
Using social media in linguistic and socio-linguistic research is becoming more prevalent, but how does it compare to other methods? We argue that Twitter has some multimodal advantages including providing cognitive linguistic researchers with multimodal data and also in providing "instant" metaphors that are elicited from very specific contexts and bodily experiences. We first review some cognitive data that summarizes the embodied, online nature of language processing and then we present data from 3 different corpora: a COCA corpus, a laboratory experiment, and a corpus made from Twitter data. These methods are compared and discussed in terms of ease of use and contributions to questions of interest for cognitive linguists. Results show that the twitter data is relatively easy to collect, contains many multimodal data points, and also elicits "instant" metaphors that are difficult to find/elicit using other methods.
\end{abstract}

Keywords: Multimodal, Instant Metaphors, Twitter, Social Media, Cognitive Linguistics, Embodied Simulations

Resumo: O uso de mídias sociais na pesquisa linguística e sociolinguística está se intensificando, mas como isso se compara a outros métodos? Argumentamos que o twitter apresenta algumas vantagens multimodais, incluindo fornecer dados multimodais a linguistas cognitivos, assim como fornecer metáforas 'instantâneas' geradas a partir de contextos e experiências corpóreas muito específicos. Primeiro, analisamos alguns dados que resumem a corporeidade do processamento da linguagem natural online e, então, apresentamos dados gerados a partir de três corpora distintos: do corpus COCA, de um experimento de laboratório, e de um corpus feito a partir de dados do twitter. Esses métodos foram comparados e discutidos em termos de facilidade do uso e contribuições para questões pertinentes para linguistas cognitivos. Os resultados apontam que os dados do twitter são relativamente fáceis de coletar, contém muitos dados multimodais, e também podem elicitar metáforas 'instantâneas' que são difíceis de encontrar/elicitar utilizando outros métodos.

Palavras-chave: Metáforas multimodais instantâneas, Twitter, Mídias sociais, Linguística Cognitiva, Simulações Corporificadas. 


\section{Introduction}

When we think of multimodal data, we often think of verbal and gestural analyses or we may think of systematically priming participants by stimulus designed for a particular sensory system: visual, proprioceptive, auditory, or even olfactory/gustatory. Yet, as of now, not many metaphor scholars have considered the use of twitter data to understand more natural use case scenarios. Consider the woman from Bristol, England who tweeted: "Gonna be on my fucking period in boomtown, souuuunndd thanks "Mother Nature" (Ferreira \& Okonski, 2018). In this case, the woman is having a very particular embodied experience. She is simulating how her menstruation will ruin her time in "boomtown" and sarcastically thanking "Mother Nature." The multimodal experience that created this tweet was most likely pre-menstrual cramps that coincided exactly with the last few days before this woman was to leave on vacation. We argue here that the exact timing of these cramps with other meaningful life events produce an online context that is unlikely to be captured in a laboratory setting mainly because (1) the chances of catching a female participant at the exact time in her cycle, and at exactly the right time of day, and before she has taken a pill to dull the sensation are quite slim and (2) because once that moment passes the online nature of the simulation will fade rapidly.

In addition to the multimodal context that elicited the tweets, tweets can also produce multimodal data because people often link photos to their tweets. A simple series of emoticons can signal rich information in a metaphorical context. A frowny face can signal sarcasm after an ostensibly positive message, a source domain can be brought to life with a nature emoji, or even an entire song can be added as a soundtrack to the metaphorical experience.

In order to describe how researchers can use twitter to gather such multimodal data, we will first review the cognitive literature describing the importance of capturing "online" measures. Secondly,

\footnotetext{
${ }^{1}$ We use bold underlined to highlight figurative, metaphorical meaning.
}

we will describe three data sets that we collected to explore Mother Earth metaphors and how each methodology produced slightly different results. Specifically, we argue that multimodal Twitter data reveals exciting insights about the multimodal, embodied conditions that elicit these metaphors in an online context. Finally, we will discuss some methodological considerations to consider when using twitter data in psycholinguistic or cognitive linguistic work.

\section{Simulation}

George Lakoff is a legend for his contributions beyond linguistics, namely for introducing cognitive science to embodied cognition. Embodied metaphor theory has important cognitive implications precisely because it is embodied. The main hypothesis is that all semantic knowledge, even abstract language, relies on embodied experience and simulations. Embodied simulation refers to the idea that recreate the concrete aspects of experience in our minds when we understand language (Bergen, 2012, p. 13; Gibbs, 2006). Since Lakoff and Johnson put forth their influential Conceptual Metaphor Theory in 1980, psycholinguistic and cognitive neuroscience research has provided evidence in support of this idea of simulation.

One classic study presented people with sentences such as "The carpenter hammered the nail into the wall." After reading the sentence, participants were shown a picture of an object, such as a horizontal or vertical nail or an unmentioned distractor item (i.e. elephant). They were asked to quickly judge whether the pictured object was mentioned in the sentence. People, on average, were faster to make their "yes" decisions when the picture was in the same spatial orientation as implied by the sentence they just read (Stanfield \& Zwaan, 2001). This pattern of results suggests that participants are simulating the implied orientation of objects when they are interpreting sentences.

In a similar study, Zwaan and colleagues found that, when participants read sentences about an eagle 
in a nest, they were quicker to verify an eagle with its wings tucked. Likewise, when they read a sentence about an eagle in the sky, participants were quicker to verify an eagle with its wings spread (Zwaan, Stanfield, \& Yaxley, 2002). Once again, people are simulating the shapes of objects when they process language. These results suggest that simulations are dynamic because participants do not prefer any depictions of a nail or eagle equally, they prefer the depictions of the nail and the eagle that match the linguistic context that they just read. The context provides nuanced information and these contextual details are incorporated in simulations.

In a similar line of inquiry, cognitive neuroscience researchers tested to see whether action verbs create body specific neural simulations (Hauk, Johnsrude \& Pulvermueller, 2004). Participants were asked to engage in a passive reading task. Hemodynamic response was collected using event related fMRI. Participants showed increased activation in the motor and premotor cortex in body specific areas when they read body specific action verbs so that when they read words like "lick" the areas showing increased hemodynamic response overlapped with the areas of the motor and premotor area which were previously determined to control mouth related action. This experiment illustrates that simply reading a word can activate embodied simulations even when the body itself is not in action. Previous, entrenched knowledge of the body in action contributes to people's embodied understandings of action verbs.

Several lines of experimental research support the claim that people experience embodied simulations when interpreting metaphorical language. One test of the embodied simulation hypothesis examined people's speeded understanding of metaphorical phrases such as "grasp the concept" (Wilson \& Gibbs, 2007). Participants first learned to associate particular symbols with particular bodily actions. For example, when they saw the symbol (") they learned to produce a grasping movement. After this training phase, participants then sat in front of a computer, saw an icon, enacted the action, and then were presented with a metaphoric statement to understand as quickly as possible. The results showed that making, or imagining making, a relevant body action (e.g., a grasping motion) facilitated the time it took people to read and understand the metaphorical statements. Even if people are unable to physically grasp a concept, engaging in relevant body actions primes the construction of an embodied simulation to infer the metaphorical meaning of "grasp the concept." Neuroscience work also showed activation in the motor system of participants' brains when they read both literal (e.g., "grasped the stick") or metaphorical (e.g., "grasped the idea") statements (Desai et al., 2012), which offers additional evidence that embodied simulations may be the foundation of our understanding of metaphorical meanings.

Taken together, these results further suggest that metaphor comprehension is embodied and dynamic. Not only are embodied neural resources activated when metaphorical phrases are accessed as the neuroscience results suggest (ibid.), but this also indicates that there is a dynamic relationship between bodily experiences, mental simulation, and metaphorical comprehension. Again, this work suggests that simulations associated with metaphoric thought are not static, discrete representations that we access the same way every time. Rather, evidence suggests that context plays a crucial role in the embodied simulation process. Embodied simulations, constructed on the fly, play an important role in people's interpretation of metaphorical language. Still, how do these simulations impact thought on a cognitive time scale?

\section{Online Processing}

The term "online" when used in a cognitive context refers to capturing data at the exact time of an experience when emotions, cognitive appraisals, and physiological reactions are at their peak. In this way, online methods and measures are intrinsically more embodied and multimodal in nature. Richard Lazarus, researcher famous for his work on cognitive appraisal theory of emotions, once conducted a study, which sought to emphasize the role of cognition in the outcome of emotional experience (Lazarus \& Alfert, 
1964). The author wanted to show that, even if emotions happen very rapidly and seemingly without introspection, that they still rely on cognitive appraisals that unfold very quickly. In this study, they used an anthropological film depicting a young boy who is approached by an elder with a sharp rock. He placed participants into four experimental conditions and primed them to think of the video in a certain way that might influence their cognitive appraisals and therefore their emotions. The participants in this study were all young men. They all saw the same video but heard different soundtracks designed to make the event seem more neutral as if they were anthropologists or more traumatic. They wanted to see if the way the participant's framed the event would change their emotional responses. He asked the young men to self-report their emotional arousal after the video and their self-report measures showed very few differences. Was this simply because men are socialized not to display their emotions? Were they hiding their emotions because of socialized gender display norms? Alternatively, was this null result a product of their offline self-report measure?

A replication of this study (Speisman et al 1964) provided further insight. In this experiment the researchers stopped the video periodically to get their reactions while the video was playing instead of after the game was over. They also used online physiological measures (heart rate and skin conductance). In this study, both the self-report data and the physiological data showed that the primes had powerful effects on the participant's emotional responses. The denial and intellectual conditions reduced emotional reactions to the video compared to the control group and the trauma condition elevated emotional reactions. The only reason that researchers were able to find this result is because they used an online measure.

Thus, it appears that people have emotional reactions at the time of the experience. In another experiment, participants played a video game where you can collect gold (a positive event) or you can be killed by a monster (a negative event). People would play this event and learn where the gold and monsters were inside the game. They came in for the study on the second day but this time the experimenters had modified the game so that in crucial places an unexpected event would happen: there would be a bigger pile of gold or an unexpected monster lurking. Again, online measures were used to show that, during unexpected events in particular, heart rates and galvanic skin responses would increase (MacDowell \& Mandler, 1989).

Timing is also crucial in the context of online embodied simulations. This can be seen in an effect known as the Action Compatibility Effect (ACE). Researcher's find that when the participant comes across a sentence that implies the motion that their hand will make, this can facilitate their comprehension of the sentence and speed up the reaction time. However, researchers have had to really fine tune the timing of these experiments down to the milliseconds because they must align perfectly with action planning, so that participants have had time to prepare and execute the motor response while processing the sentence (Borreggine \& Kaschak, 2006). If the experiment is even 100 milliseconds off they may find that the motor resources are competing for the same resources and instead inhibit responses or if they are too late they may find no effect at all.

Metaphorical simulation can also be found through online, multimodal data. For example, a unique TIME IS SPACE metaphor was documented by Raphael Nunez and Eve Sweetser (2006). They investigated the metaphors of the Aymara language spoken in a region that is at the border of Bolivia, Peru, and Chile, this language is native to the region but in modern times is being culturally infiltrated by the surrounding Spanish-speaking Latin American cultures. This makes for a fascinating mixture of metaphors because the Aymara TIME IS SPACE metaphors locate the future behind you and the past in front of you. This idea is related to the metaphor KNOWING IS SEEING; you know what happened in the past because you can see it. However, the Spanish language has the opposite TIME IS SPACE metaphor where the speaker is travelling towards the future and the future is in the front while the past is behind. 
Based on this cultural difference one would predict the elder native speakers with no Spanish knowledge to conceptualize the future behind their body and the younger Spanish speakers with less indigenous language knowledge to conceptualize the future in front of their body. A gestural analysis of speakers revealed that older participants over the age of 65 displayed FUTURE IS BEHIND congruent gestures while they spoke while only one speaker younger than 65 showed these indigenous figurative gestures. The younger speakers seem to be adopting the Spanish/Westernized metaphors for time while the older generation maintains the traditional metaphors as evidenced by their respective gestures. These behavioral results, in combination with the linguistic instantiations of metaphor, suggest that the conceptual metaphors within a language shape spatial representations of time.

A second online study by Brian Meier and colleagues (2007) looked at the vertical metaphors associated with religious concepts: GOD/HEAVEN IS UP and SATAN/HELL IS DOWN. In a series of studies, they found that, when stimuli are presented in a spatial location congruent with the metaphorical structure, participants encode concepts faster. These researchers used a test called the Implicit Associations Test which uses very rapid reaction times to reveal implicit conceptual associations. These tests can be used to test the implicit associations between racism and justice in such a way that even famous civil rights lawyers reflect these implicit cognitive biases which are, not necessarily personal beliefs, but rather deeply entrenched socio-cultural constructions. In this case, the researchers used this as a clever way to test metaphorical strength to validate the concept of using simulations during abstract language comprehension.

These studies are all fascinating displays of empirical psychology but they may be impractical for the cognitive linguist to actually implement. Online measures such as heart rate, GSR, mouse tracking, and response time can be very tricky to implement and, at times, outside the scope of expertise of the cognitive linguist. One of the strengths of corpus data is that researchers can go beyond general metaphors to reveal nuanced usage scenarios that speakers apply in the real world.

We aim to demonstrate here that using twitter as a corpus may be a way for cognitive linguists to tap into multimodal data and the multimodal contexts that produce some of the most embodied, naturalistic language use without having to simulate those eliciting conditions in a lab and without attempting to apply online cognitive methodologies.

Indeed, in terms of linguistic data, even a 200 ms difference can be a huge effect as our cognitive system works at lightning speed (Winters, In Press, p.31). The proposed Twitter corpus method can't get at online cognitive differences at the millisecond level. However, it can be quite useful to understand the "online" metaphors that emerge in embodied, situated contexts and can operate in longer durations (long enough for people to tweet about it). This may still operate on a time scale where we see more situated online experiences than what we often see in cognitive experiments. These durations may not be long enough to be detected in the laboratory interview at a later date, removed from the embodied, emotional, social, cultural, and generally more meaningful context.

These metaphors that we are interested in are known as situated "instant" metaphors (Romano, 2013). They are characterized as being situated, instant, and context induced. Furthermore, they are noted for their multimodal creativity. These metaphors are highly activated if you consider them according to Cornelia Mueller's continuum of metaphorical dynamics in Figure 1 (Müller, 2008). In the next section we will introduce some examples from our corpus data, our twitter data and data collected in a laboratory context to illuminate the multimodal creativity found in the twitter data.

Figure 1

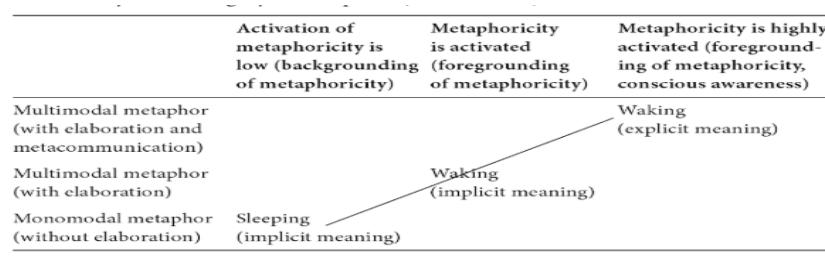




\section{Regular Corpus Data}

Before introducing the twitter data, we will briefly explain what we found in COCA (Davies, 2008) and in an online laboratory study. A COCA analysis revealed some common entailments associated with the Mother Earth metaphor (frequency $=1,119$ examples). Each time an example included a metaphorical entailment, this was counted as one instance so that if every example talked about a particular theme one or more times the maximum score for that theme would be 1,119. The metaphorical frequencies are listed below in Table 1:

Table 1:

\begin{tabular}{|c|c|c|}
\hline $\begin{array}{l}\text { Metaphorical } \\
\text { Entailments }\end{array}$ & Examples & Frequency \\
\hline $\begin{array}{l}\text { Woman's } \\
\text { Body: Water } \\
\text { as Womb/ } \\
\text { Environmental } \\
\text { Destruction as } \\
\text { Rape/ } \\
\text { Physical } \\
\text { Attributes }\end{array}$ & $\begin{array}{l}\text { "Moved by external } \\
\text { instrumental force, } \\
\text { moral sanctions } \\
\text { (against ravaging the } \\
\text { womb of Mother Earth } \\
\text { for minerals, for } \\
\text { example) gave way to } \\
\text { unrestrained license } \\
\text { to exploit female } \\
\text { resources." }\end{array}$ & $N=9$ \\
\hline $\begin{array}{l}\text { Harsh } \\
\text { Weather as } \\
\text { Anger/Punish } \\
\text { ment }\end{array}$ & $\begin{array}{l}\text { "There's no question } \\
\text { Mother Earth is } \\
\text { venting." }\end{array}$ & $N=8$ \\
\hline $\begin{array}{l}\text { Natural } \\
\text { Resources as } \\
\text { Gifts, Bounty, } \\
\text { Riches, and } \\
\text { Commodity }\end{array}$ & $\begin{array}{l}\text { "Receiving beautiful } \\
\text { Mother Earth's } \\
\text { bounty-her crops, her } \\
\text { oil, her precious } \\
\text { metals and } \\
\text { diamonds." }\end{array}$ & $N=16$ \\
\hline $\begin{array}{l}\text { Polluting/ } \\
\text { Destruction as } \\
\text { Disrespect, } \\
\text { Abuse, Stress, } \\
\text { Neglect, } \\
\text { Sickness, and } \\
\text { Greed }\end{array}$ & $\begin{array}{l}\text { "Confronted by an oil } \\
\text { spill, one of } \\
\text { humanity's more } \\
\text { dangerous } \\
\text { assaults on Mother } \\
\text { Earth." }\end{array}$ & $N=11$ \\
\hline $\begin{array}{l}\text { Preserving/ } \\
\text { Protecting/ } \\
\text { Replenishing } \\
\text { as } \\
\text { Commitment, }\end{array}$ & $\begin{array}{l}\text { "It would put a cool } \\
\text { compress on Mother } \\
\text { Earth's supposedly } \\
\text { fevered brow." }\end{array}$ & $N=11$ \\
\hline
\end{tabular}

\begin{tabular}{|l|l|l|}
$\begin{array}{l}\text { Honor, } \\
\text { Kespect, } \\
\text { Health }\end{array}$ & \\
\hline $\begin{array}{l}\text { People of } \\
\text { Earth as } \\
\text { Children/Famil } \\
\text { y }\end{array}$ & $\begin{array}{l}\text { "The sentiment that } \\
\text { our civilization is like a } \\
\text { dysfunctional family } \\
\text { estranged from } \\
\text { Mother Earth." }\end{array}$ & $\mathrm{N}=8$ \\
\hline $\begin{array}{l}\text { Connection } \\
\text { with the Land } \\
\text { as Connection } \\
\text { to Mother }\end{array}$ & $\begin{array}{l}\text { "You can throw } \\
\text { yourself flat on the } \\
\text { ground, stretched out } \\
\text { upon Mother Earth, } \\
\text { with the certain } \\
\text { conviction that you } \\
\text { are one with her and } \\
\text { she with you." }\end{array}$ & \\
\hline $\begin{array}{l}\text { Women as } \\
\text { nature, man as } \\
\text { civilization }\end{array}$ & $\begin{array}{l}\text { "It was the work of } \\
\text { civilization, of man } \\
\text { taming unruly Mother } \\
\text { Earth." }\end{array}$ & $\mathrm{N}=10$ \\
\hline
\end{tabular}

This study clearly helped us to outline some of the most common metaphorical themes which helped us inform our predictions for our follow up studies on this topic. However, some of this data is from journals. Indeed, many examples were thrown out as they referred to a magazine with "Mother Earth" in the title. Other phrases seem more formal than usage based.

\section{Online Structured Interview Data}

This data was collected in an online experiment using a structured interview developed in a psycholinguistics laboratory. Twenty-eight undergraduate students received class credit to participate $(\mathrm{N}=28)$. The interview consisted of a set of questions designed to elicit information about the participant's understanding of the Mother Earth metaphor.i Each time an interview contained at least one metaphorical theme this was counted as present for that participant so that if every participant talked about a particular theme one or more times the maximum score for that theme would be 28 . The data from this analysis is shown below in Table 2: 
Table 2:

\begin{tabular}{|c|c|c|}
\hline $\begin{array}{l}\text { Metaphorical } \\
\text { Entailments }\end{array}$ & Examples & Frequency \\
\hline $\begin{array}{l}\text { Woman's Body: } \\
\text { Water as Womb/ } \\
\text { Environmental } \\
\text { Destruction as } \\
\text { Rape/ } \\
\text { Physical } \\
\text { Attributes }\end{array}$ & $\begin{array}{l}\text { "saw a tweet that } \\
\text { said (paraphrasing) } \\
\text { 'Im tryna dig a hole } \\
\text { in the ground and } \\
\text { fuck mother earth." }\end{array}$ & $N=2$ \\
\hline $\begin{array}{l}\text { Harsh Weather } \\
\text { as } \\
\text { Anger/Punishme } \\
\text { nt }\end{array}$ & $\begin{array}{l}\text { "I think it comes from } \\
\text { this idea that } \\
\text { females are gentle } \\
\text { and caring, but also } \\
\text { can be dangerous } \\
\text { and aggressive if } \\
\text { you cross them." }\end{array}$ & $N=3$ \\
\hline $\begin{array}{l}\text { Natural } \\
\text { Resources as } \\
\text { Gifts, Bounty, } \\
\text { Riches, and } \\
\text { Commodity }\end{array}$ & $\begin{array}{l}\text { "I think it means to } \\
\text { see the earth as a } \\
\text { living thing that } \\
\text { always gives all it } \\
\text { has for your disposal } \\
\text { and that we } \\
\text { shouldn't just } \\
\text { constantly take to } \\
\text { profit off of but treat } \\
\text { the earth as if it was } \\
\text { your mother, } \\
\text { someone you care } \\
\text { about and want to } \\
\text { protect and heal, not } \\
\text { damage." }\end{array}$ & $N=20$ \\
\hline $\begin{array}{l}\text { Polluting/ } \\
\text { Destruction as } \\
\text { Disrespect, } \\
\text { Abuse, Stress, } \\
\text { Neglect, } \\
\text { Sickness, and } \\
\text { Greed }\end{array}$ & $\begin{array}{l}\text { "To think about the } \\
\text { earth as a mother } \\
\text { means that there is a } \\
\text { force stronger than } \\
\text { all of us and we are } \\
\text { inhabiting life with } \\
\text { her children and } \\
\text { sometimes we } \\
\text { create destruction } \\
\text { upon her children } \\
\text { (plants, water, etc)" }\end{array}$ & $\mathrm{N}=7$ \\
\hline $\begin{array}{l}\text { Preserving/ } \\
\text { Protecting/ } \\
\text { Replenishing as } \\
\text { Commitment, } \\
\text { Honor, Respect, } \\
\text { Kindness and } \\
\text { Health }\end{array}$ & $\begin{array}{l}\text { "Yet we have to } \\
\text { appreciate what the } \\
\text { Earth gives us by } \\
\text { taking care of it, just } \\
\text { as a person would to } \\
\text { their mother." }\end{array}$ & $N=19$ \\
\hline $\begin{array}{l}\text { People of Earth } \\
\text { as } \\
\text { Children/Family }\end{array}$ & $\begin{array}{l}\text { "I think it depicts } \\
\text { humanity as an } \\
\text { adolescent still } \\
\text { growing and learning } \\
\text { and we're under the } \\
\text { care and support of }\end{array}$ & $N=8$ \\
\hline
\end{tabular}

\begin{tabular}{|l|l|l|} 
& \multicolumn{1}{|l|}{$\begin{array}{l}\text { the Earth until we } \\
\text { reach maturity" }\end{array}$} & $\mathrm{N}=4$ \\
\hline $\begin{array}{l}\text { Connection with } \\
\text { the Land/Water } \\
\text { as Connection to } \\
\text { Mother Earth }\end{array}$ & $\begin{array}{l}\text { "At times when I am } \\
\text { at the beach I can } \\
\text { feel my body relax } \\
\text { as the waves calm } \\
\text { down or i'll feel the } \\
\text { strength that from } \\
\text { the waves crashing } \\
\text { onto shore or cliffs." }\end{array}$ & \\
\hline $\begin{array}{l}\text { Women as } \\
\text { nature, man as } \\
\text { civilization }\end{array}$ & NA & $\mathrm{N}=0$ \\
\hline
\end{tabular}

The analysis presented here in table 2 displays preliminary findings from a pilot study and is strictly an analysis of metaphorical themes elicited in the qualitative data. Using a structured interview is another method for corpus analysis which allows more focused data to be elicited. For example, we were interested specifically in whether or not participants had any embodied simulations that they were consciously aware of when thinking of the mother earth metaphor (for more on this methodology see also Okonski \& Gibbs, In Press). This yielded insightful observations such as one participant who noted that the destruction of earth was similar to the feeling of burns and scars, another noted that blood and the head were relevant, and one participant wrote that they experienced "pain when i read or see something that is harming the planet but happy and warm when i see people doing community service that benefits the earth." These responses yield surprising results that some participants do consciously experience feelings and emotions when considering the metaphor.

The ability to collect specific data in response to carefully constructed eliciting questions is clearly a benefit to this technique. This yielded slightly different results than the COCA data. For example, this data is more difficult to collect. The cognitive linguist must complete an ethics training and apply to an ethics committee to obtain permissions to use human subjects. The researcher must also obtain permissions to do such research within a competitive 
research environment where participants are a limited resource. They must then follow strict protocol for analyzing, storing and presenting the data. Thus, the data sets here will be considerably smaller than what can be obtained very quickly from an online corpus such as COCA or from an open access source such as twitter.

Another potential criticism to this method is that we explicitly elicit the knowledge using prompts that could priming participants with the metaphor within the questionnaire. In addition, the use of undergraduate, university students has come under great scrutiny (Heinrich et al., 2010). Undergraduate students in the US who tend to be less diverse and more privileged than most people in the world (ibid). In contrast to the undergraduate data, the COCA corpus consists of some spoken data but that data is generally sourced from more formal contexts such as TV and radio programs. The rest of the corpus is also not from an everyday context but rather is sourced from fiction, magazines, newspapers, and even academic journals. While COCA data is certainly useful to find metaphorical themes, it should be noted that these contexts may not generate the spontaneous kinds of embodied instant metaphors that could be found in a twitter corpus and may be even less diverse than the data taken from university students.

In conclusion, while the interview method has some shortcomings, collecting data from only 28 participants was sufficient to find many instances of the metaphorical entailments found in the COCA corpus and enabled the researchers to elicit very specific types of data including some very interesting self-reports about embodied simulations associated with the Mother Earth metaphor.

\section{Twitter Data}

Our corpus collected from twitter was taken over a 7-day period from August $1^{\text {st }}$ to August $7^{\text {th }}$ in 2017. We were able to collect 521 tweets in English and in Portuguese using the phrases "Mother Earth" or "Mother Nature" or respectively "Mãe Terra" or "Mãe Natureza." While this seems to be another obvious advantage to collecting twitter data, we will focus here on the English data $(\mathrm{N}=332)$ to illustrate a couple of ways that this data set differed from our other data set. Each time a tweet contained at least one metaphorical theme this was counted as present for that tweet so that if every tweet talked about a particular theme one or more times the maximum score for that theme would be 332 . Table 3 displays the frequency of the metaphorical themes in the twitter data:

Table 3

\begin{tabular}{|c|c|c|}
\hline $\begin{array}{l}\text { Metaphorical } \\
\text { Entailments }\end{array}$ & Examples & Frequency \\
\hline $\begin{array}{l}\text { Woman's } \\
\text { Body/ Water } \\
\text { as Womb/ } \\
\text { Environmental } \\
\text { Destruction as } \\
\text { Rape }\end{array}$ & $\begin{array}{l}\text { "RT @_TooCrazyFox: I just } \\
\text { woke up, is Donald Trump } \\
\text { still butt fucking mother } \\
\text { nature to the shivers of } \\
47 \% \text { of Americans who } \\
\text { can't see thru" }\end{array}$ & $N=24$ \\
\hline $\begin{array}{l}\text { Harsh } \\
\text { Weather as } \\
\text { Anger/Punish } \\
\text { ment, Power } \\
\text { over Weather }\end{array}$ & $\begin{array}{l}\text { "@adamcbest Mother } \\
\text { Nature, appearing as } \\
\text { Climate Change, just told } \\
\text { the GOP/admin, via } \\
\text { Louisiana and an August } \\
\text { twister, to go f\#\#k } \\
\text { themselves!!" }\end{array}$ & $N=28$ \\
\hline $\begin{array}{l}\text { Natural } \\
\text { Resources as } \\
\text { Gifts, Bounty, } \\
\text { Riches, } \\
\text { Commodity, } \\
\text { Nourishment }\end{array}$ & $\begin{array}{l}\text { \#mothernature you rock. All } \\
\text { this picked round the } \\
\text { corner in a local bit of } \\
\text { scrub. } \\
\text { \#III \#freefood \#bramble \#bla } \\
\text { ckberry }\end{array}$ & $N=34$ \\
\hline $\begin{array}{l}\text { Polluting/ } \\
\text { Destruction as } \\
\text { Disrespect, } \\
\text { Abuse, Stress, } \\
\text { Neglect, } \\
\text { Sickness, and } \\
\text { Greed }\end{array}$ & $\begin{array}{l}\text { "Another assault on } \\
\text { Mother Earth! What's } \\
\text { next? Open season in our } \\
\text { zoo's! \#WakeUpAmerica } \\
\text { \#WakeUpGOP } \\
\text { \#NeverAgain \#impeach } \\
\text { \#BlueWave" } \\
\text { Kamala Harris @SenKamalaHa } \\
\text { Something you're not hearing in th } \\
\text { whether to shrink/eliminate some }\end{array}$ & $N=26$ \\
\hline
\end{tabular}




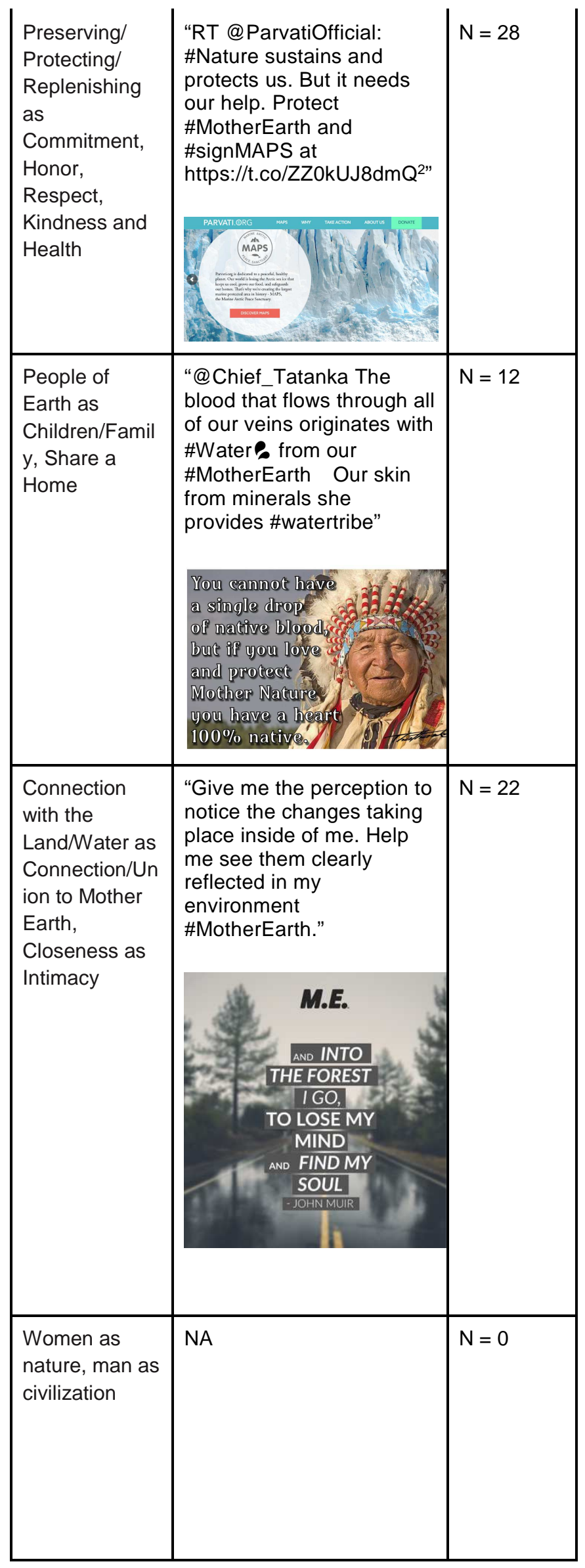

${ }^{2}$ Link to pavati.org, an artic marine preservation group
One way that the data set differed is that, in contrast to corpus and lab collected data, the people in the twitter data were sometimes actually experiencing nature when they were tweeting instead of simply reflecting about nature more generally or trying to remember a time when had experienced nature. Again, the online processing here during the metaphor use, the multimodal experience of nature increases ecological validity for this data set and captures richer metaphorical contexts as they naturally occur.

Consider this example tweeted by a US English speaker: "In $\bullet$ with Big Bear $\otimes$ \#bigbear \#mountains \#mothernature \#nature \#stunning \#thetop \#bigbearlake..." This woman was writing about mother nature as if she were a romantic partner using words and phrases like "in love" and "stunning" to describe a part of nature, crucially the part of nature that she was currently enjoying. This is really getting at the online processing of the metaphor when the person is actually immersed in the full peak experience with all of its emotions and the corresponding physiological arousal.

Many social psychologists are already using social media to investigate context specific events that are crucially time locked such as political events. In our case, given tha interest in mother nature metaphors, we could again collect another data set just after a natural disaster or just after an important election to see how the metaphors might change according to context. We might also collect another set of data from the week after the UN Climate Report was released in October, 2018 while people are actually coming to terms with one of the most devastating reports on climate change yet to be released. This ability to update the corpus or to collect data during a particular event makes this corpus much more dynamic than any other corpus available.

This corpus data is also multimodal in and of itself. Tweets often include emoticons, photos, links to websites, retweets and even music videos and other web based movies. Overall, most tweets were multimodal containing an emoticon or a link to other related media $(N=252)$. Some emoticons depicted the source domain of the planet earth or other aspects 


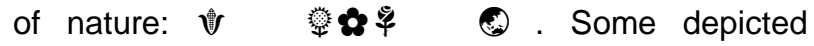
emotional states, for example a cheeky tweet had a winky face (-) and a male tweeter used the emoticon with sunglasses after letting us know that he is "mother earth's bitch in a manly way." In another instance, the emoticon adds context to decipher the meaning in the tweet: "Wouldn't be the same if it didn't rain on the weekend (:) \#mothernature." In this example, the frowny face constrains the meaning of the sentence so that the reader can infer that the rain is negative in this case giving the overall sentence a sarcastic dimension.

Overall, there were 11 different face emoticons used and 5 different hand and arm tweets to depict different emotional states. People also used green, red and yellow hearts in their tweets and water droplet emoticons.

See Figure 2 to view a photo of where the tweet from Big Bear was authored from a gorgeous landscape of mountains covered in green trees. Another tweet linked to a youtube video called "The Overview Effect" which follows 5 astronauts who see the earth from space in order to describe the phenomenon and importance of this effect in relationship to the environment (See Figure 3 to view a screenshot from this video). These types of multimodal data aren't usually available in other corpora.

Figure 2

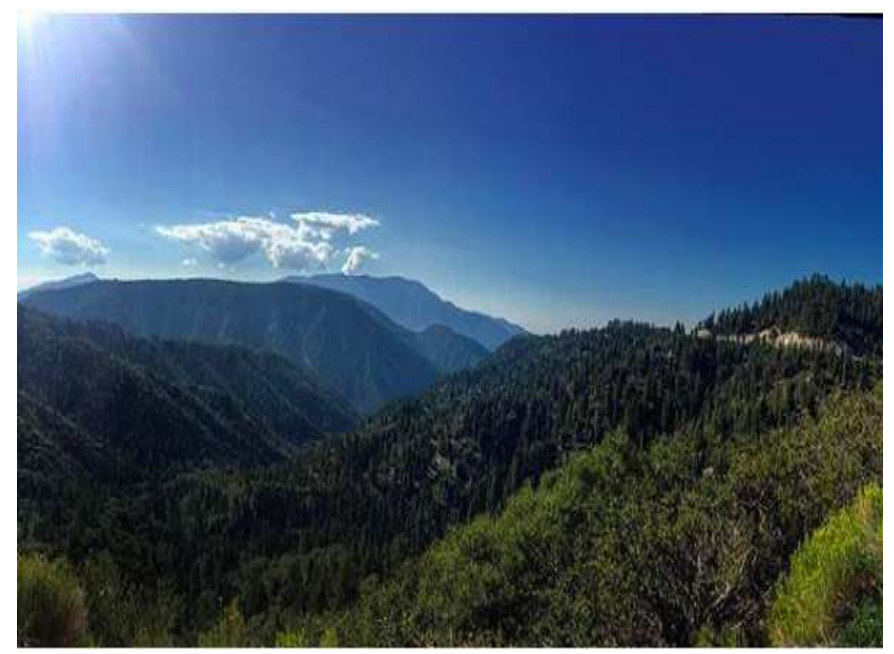

Figure 3

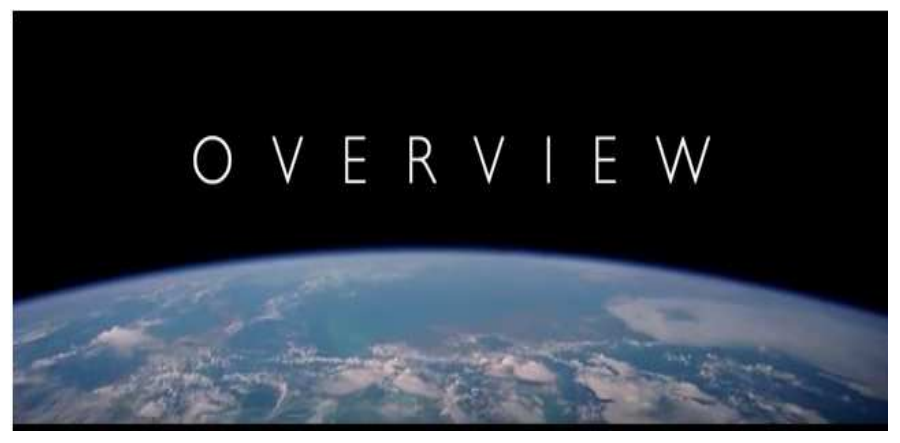

Other types of linked media added a sociocultural element. For example, one angry biker who thought cars should be grateful that he is saving gas linked the YouTube video for the Audioslave song titled "Gasoline." In another instance, there was a link included to an event in the Peruvian/Bolivian Andean Highlands depicting the celebrations of "Pachamama." ${ }^{3}$ Pachamama is the local Mother Earth Goddess in that region. This provided much cultural knowledge about traditions surrounding Pachamama culture and the way that they conceptualize this specific example of Mother Earth. Figures 4 to 8 depict the Pachamama celebration along with the captions describing the actions depicted in the photos.

Figure 4

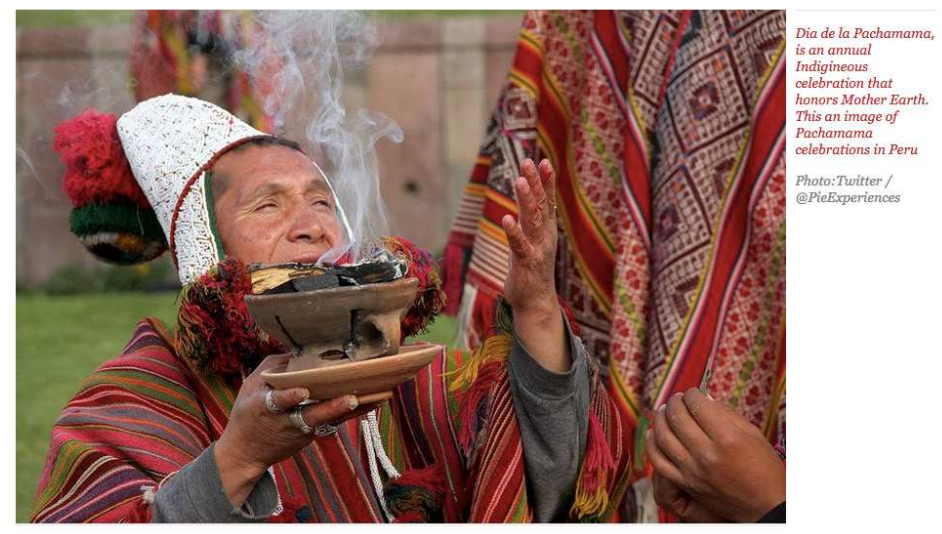

https://www.telesurenglish.net/news/Pachamama-MotherEarth-Day-20170801-0029.html 
Figure 5

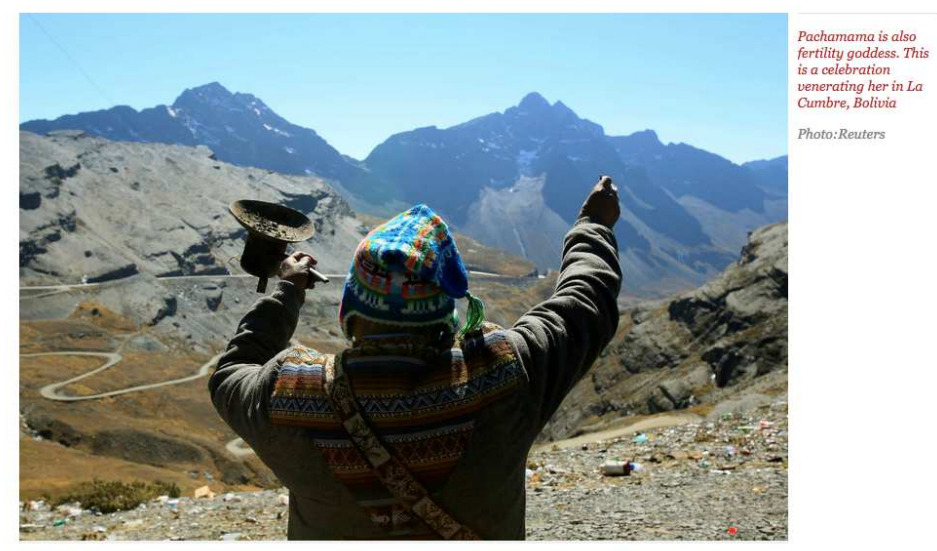

Figure 6

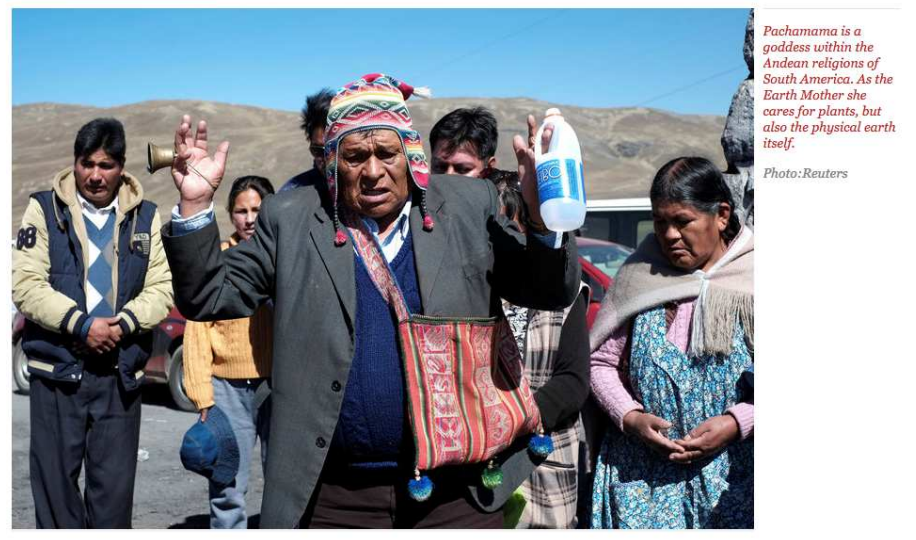

Figure 7

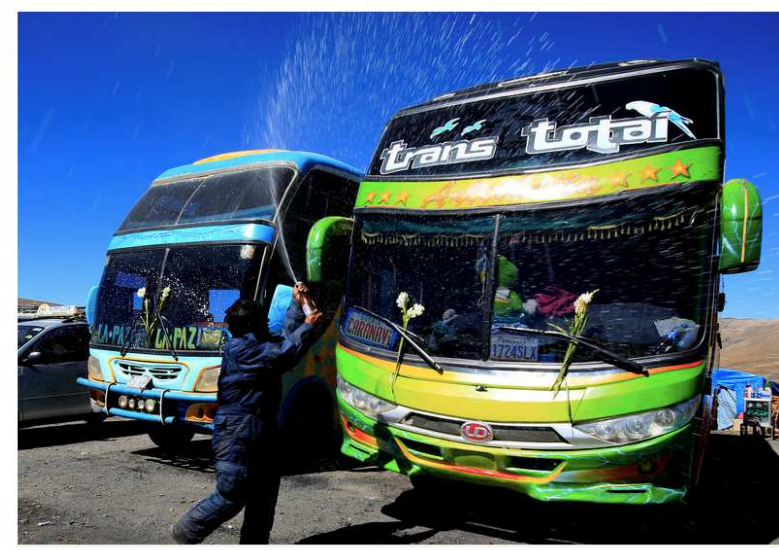

Figure 8

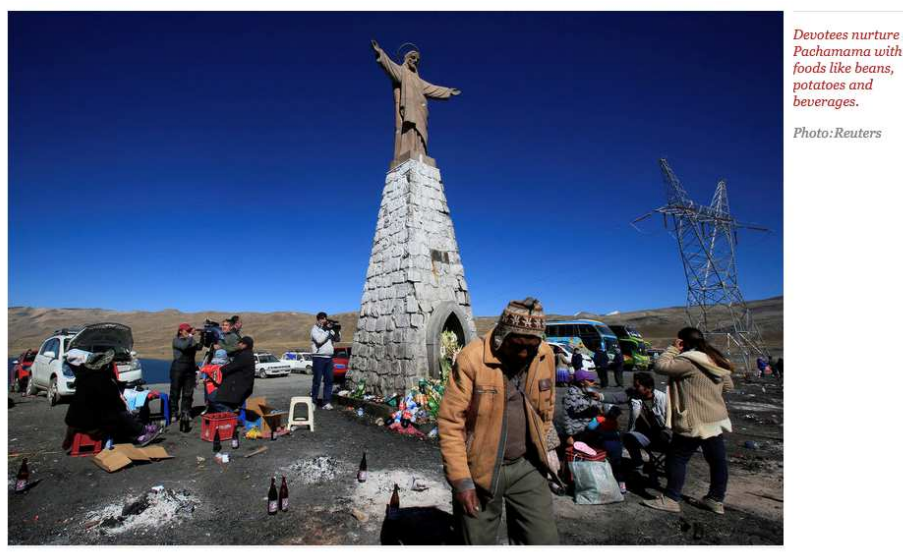

Finally, we found metaphorical cases used in the twitter corpus that we didn't find in the Davie's corpus nor in the lab including female experiences of menstruation. One feasible hypothesis about this finding is that people may not disclose something this sensitive and private in a laboratory study There are several reasons why this may not account for not finding this example in our data. First, participants did share other examples that might be considered inappropriate such as the participant who noted, "Im trying to dig a hole in the ground and fuck mother earth" in a laboratory study. Second, the likelihood of having that exact physical experience in the lab at the exact time of answering the questionnaire is small. This is an example of online processing that would be extremely hard to replicate in a laboratory study. The Twitter data revealed 6 examples of participants who evoked Mother Earth metaphors in relationship to their period. This is an example of an instant metaphor that depends on the individuals current, online, embodied experiences. Another example of this sort of individual metaphor that is brought about by immediate bodily situations included a woman who was stung by a caterpillar and included a picture of the swelling on her arm and neck. In one case, a mom who was watching her little boy experience tummy pains invoked the mother nature metaphor so although she was not directly experiencing the pain, she was likely simulating the pain that her child was feeling at the time. Using Twitter data was very interesting in this respect because it provided these online bodily experiences as eliciting conditions for metaphor use that was found neither in the corpus nor the lab collected data.

\section{Methodological Considerations \& Conclusions}

This article summarizes data generated from 3 different qualitative-quantitative corpus analyses including a more traditional COCA analysis, an online laboratory structured interview questionnaire, and a corpus constructed from Twitter data. All three methods revealed similar metaphorical themes. The COCA data is relatively easy to retrieve being located in a free, online database constructed explicitly for this purpose. This method is arguably the most accessible 
of the three methods addressed in this paper. The laboratory data was the most difficult to obtain given all of the steps associated with human subjects research. However, this data did provide additional control over the type of content included. The data collected from Twitter was the only multimodal data.

Using the main metaphorical themes found in the COCA analysis, the data shows that very similar themes were also present in the other two types of corpus data, showing some coherence to the same metaphorical themes. However, the Twitter data was the only data that revealed instant, embodied metaphors. The synchronization of bodily sensations of the tweet authors at the time they were making the tweet was an important eliciting condition for these types of instant metaphors that we did not find in COCA nor in the laboratory data.

While we compared three different ways to construct a corpus for metaphor analysis, these are not the only three methods available to use. For example, we could mix Twitter data with a more controlled experimental design as well to collect insights on how tweets affect behavior. One study (McGregor, 2017) systematically exposed participants to tweets by politicians so that they either saw campaign or policy tweets (i.e. "Homelessness is an important issue that we can't allow to be swept under the rug..." or they saw personalized tweets (i.e. "our daughter passed her driving exam yesterday..."). In this way, the author was able to demonstrate the more effective political communication strategies on social media, namely, that these personalization strategies can help candidates increase a sense of intimacy with their constituents and ultimately increase the support for the candidate. This kind of methodology could be adapted to target particularly metaphorical tweets and then have participants evaluate them according to theoretically interesting criteria. For example, we could ask groups of democrats and republicans to evaluate tweets about Mother Earth in an experiment counterbalanced with other distractor tweets (tweets on other unrelated topics that would help to disguise the aim of the research) in order to understand more about how different groups react to this metaphor.
Another method that could be great for finding instant metaphors is the method used in the now famous Harlem Study conducted by William Labov and his colleagues (1968). This method uses field researchers who tape data in the context where interesting speech events might take place. This methodology is very appealing because it has a great deal of ecological validity. However, it also requires a great deal of effort as it is work intensive to conduct human subject research in such a way. Twitter data may offer up multimodal data with much greater ease and flexibility.

What is more, we wanted to offer a few suggestions to researchers who may be thinking of using Twitter for research purposes. First, all data collected should remain anonymous unless you are collecting data from a celebrity user. For example, in a paper on President Trump's use of sarcasm, he can be quoted directly. However, in a paper on Mother Earth metaphors the individual identities of the authors are kept completely anonymous. Although tweets are public domain, anonymizing the data is considered a more ethical practice.

When collecting data from Twitter, you may want to collect the data directly from the API, perhaps these kinds of more technical queries are not necessary. Twitter can be searched directly from their website. It is highly recommended that researchers screenshot each tweet, document the content of each link, and save any other relevant attachment as users can adjust privacy settings, delete their account, delete the tweet, or have their account blocked for a number of reasons. When this happens, the researcher may be blocked from important parts of their data. Hence, it is best to document all of the components of each tweet immediately when constructing the corpus.

\section{Referências}

BERGEN, Ben. Louder than words: The new science of how the mind makes meaning. New York: Basic Books. 2012. 296 p.

BORREGGINE, Kristine L.; KASCHAK, Mike P. The action-sentence compatibility effect: It's all in the 
timing. Cognitive Science, v. 30, n. 6, p. 10971112, 2006.

DAVIES, Mark. The Corpus of Contemporary American English (COCA): 520 million words, 1990-present. Available online at http://corpus.byu.edu/coca/. 2008.

DESAI, Rutvik H.; CONANT, Lisa L.; BINDER, Jeffrey R.; PARK, Haeil; SEIDENBERG, Mark. A piece of the action: Modulation of the sensory-motor region by action idioms and metaphors. Neuroimage, v. 83, p. 862-869, 2013.

FERREIRA, Luciane C.; OKONSKI, Lacey. "Comparação interlinguística das metaforas de Mãe Terra no Brasil e nos Estados Unidos." Talk presented at the meeting of the Colóquio Linguagem e Cognição: Desafios e Perspectivas Contemporâneas, August 30-31, PUC Minas, Belo Horizonte, Brazil. 2018.

GIBBS, Raymond. Embodiment and cognitive science. New York: Cambridge University Press. 2006. $337 \mathrm{p}$.

GIBBS, Raymond. Walking the walk while thinking about the talk: Embodied Interpretation of metaphorical narratives. Journal of Psycholinguistic Research, v. 42, p. 363-378, 2013

HAUK, Olaf; JOHNSRUDE, Ingrid; PULVERMÜLLER, Friedemann. Somatotopic representation of action words in human motor and premotor cortex. Neuron, v. 41, p. 301-307, 2004.

HENRICH, Joeseph; HEINE, Steven J.; NORENZAYAN, Ara. The weirdest people in the world? Behavioral and Brain Sciences, v. 33, n. 23, p. 61-83, 2010.

LAKOFF, George; JOHNSON, Mark. Metaphors we live by. University of Chicago Press: Chicago. 1980. p. 276.

LAZARUS, Richard S.; ALFERT, Elizabeth. Short circuiting of threat by experimentally altering cognitive appraisal. Journal of Abnormal and Social Psychology, v. 69, n. 2, p. 195-205, 1964.

MACDOWELL, Kathleen A.; MANDLER, George. Constructions of emotion: Discrepancy, arousal and mood. Motivation and Emotion, v. 13, n. 2, p. 105-124, 1989.
MEIER, Brian P.; HAUSER, David J.; ROBINSON, Michael D.; FRIESEN, Chris K.; SCHJELDAHL, Katie. What's "up" with God? Vertical space as a representation of the divine. Journal of Personality and Social Psychology, v. 93, n. 5, p. 699-710, 2007.

MÜLLER, Cornelia. Metaphors dead alive, sleeping, waking: A dynamic view. Chicago University: Chicago. 2008. p. 272.

NUNEZ, Raphael E.; SWEETSER, Eve (2006). With the future behind them: Convergent evidence from Aymara language and gesture in the crosslinguistic comparison of spatial construals of time. Cognitive Science, v. 30, p. 401-450, 2006.

OKONKSI, Lacey; GIBBS, Raymond. Diving into the Wreck: Can people resist allegorical meaning? Journal of Pragmatics. In press.

ROMANO, Manuela. Situated-"instant" metaphors: Creativity in the slogans for the Spanish 15-M movement. In HIDALGO-DOWNING, Laura; KRALJEVIC, Blanca (eds.), Metaphorical creativity across modes. Metaphor and the social world (special issue) v. 3, n. 2, p. 241-260, 2013.

SPEISMAN, Joeseph C.; LAZARUS, Richard S.; MORDKOFF, Arnold M.; DAVISON, Les. The experimental reduction of stress based on egodefense theory. Journal of Abnormal and Social Psychology, v. 68, n. 4, p. 367-380, 1964

STANFIELD, Robert A.; ZWAAN, Rolf. The effect of implied orientation derived from verbal context on picture recognition. Psychological Science, v. 12, n. 2, p. 153-156, 2001.

WILSON, Nicole L.; GIBBS, Raymond. Real and imagined body movement primes metaphor comprehension. Cognitive Science, v. 31, p. 721$731,2007$.

WINTERS, Bodo. Applied statistical modeling with R: Generalized linear (mixed) models with linguistic examples. Routledge: UK. In press.

ZWAAN, Rolf A.; STANFIELD, Robert A.; YAXLEY, Richard H.. Language comprehenders mentally represent the shapes of objects. Psychological Science, v. 13, n. 2, p. 168-171, 2002.

\section{COMO CITAR ESSE ARTIGO}

OKONSKI, Lacey; CORRÊA FERREIRA, Luciane. Gonna be on my fucking period in boomtown, souuuunndd thanks Mother Nature: Using Twitter to Find Multimodal Creativity and Embodied Instant Metaphors. Signo, Santa Cruz do Sul, v. 44, n. 79, p. 120-135, jan. 2019. ISSN 1982-2014. Disponível em: $<$ https://online.unisc.br/seer/index.php/signo/article/view/12851>. Acesso em: doi: https://doi.org/10.17058/signo.v44i79.12851. 